\title{
A theoretical framework for economic assessment of small-scale LNG projects
}

\author{
Pavel Tsvetkov* \\ Associate Professor, Department of Economics, Organization and Management, Saint Petersburg \\ Mining University, 199106, 21st line VI, Saint Petersburg, Russia
}

\begin{abstract}
The production of small-scale liquefied natural gas (SLNG) is a promising area of the gas industry, which allows to solve the problem of energy carriers distribution between end users. This differs SLNG from medium- and large-scale projects that concentrate LNG in hubs. The implementation of SLNG projects assumes the creation of an extensive network that allows covering vast territories that are not covered by centralized gas supply networks, rather than the development of single production capacities. In this paper, we propose a theoretical framework that allows to assess the attractiveness of SLNG networks development not only in terms of direct, but also indirect effects, which differ depending on the composition of project stakeholders, as well as on the stage of technological chain. The essence of term "flexibility" in relation to LNG projects has also been clarified.
\end{abstract}

\section{Introduction}

The production of liquefied natural gas (LNG) is one of the most dynamically developing sectors of the gas industry. This is due, firstly, to the possibility of natural gas delivery to remote regions. Secondly, it is due to the flexibility of logistics chains, which allows to significantly reduce political and regional risks, which is especially important for Russia [1].

Despite their extensive geographical distribution, traditional large- and medium-tonnage projects face the problem of LNG distribution among consumers. In this context, it is logical and natural to develop the small-scale LNG (SLNG) industry, which makes it possible to transit from sea delivery to local energy supply by river vessels, railroads, or road transport [2].

The main distinction of SLNG is the "flexibility" of the logistics chains, the definition of which is a rather time-consuming task. The flexibility of SLNG provides for a number of indirect effects [3], to grasp which is extremely difficult on the scale of a regional or national fuel and energy complex, especially given the development of many innovative projects of different scales [4]. In this regard, the purpose of this work is to develop a theoretical framework for the economic assessment of small-scale LNG projects, taking into account their indirect effects.

\footnotetext{
*Corresponding author: tsvetkov_PS@pers.spmi.ru
} 


\section{Theoretical background}

All existing methods for analyzing and evaluating energy projects and energy production in general, in one way or another, include consideration of energy or material flows, which is the basis for subsequent calculations [5]. Three main approaches, available in the scientific literature, are discussed below.

1. Value-based approaches. These include all approaches that involve evaluating a project in relation to the cost of inputs, or, conversely, the cost evaluation of results to any form of expression of inputs.

2. Approaches based on natural indicators, including methods of thermodynamic evaluation. Based on these approaches, as a rule, an assessment of technical efficiency of energy projects is carried out, for example, on the basis of the analysis of exergy, enthalpy, or generalized indicators of energy consumption and energy generation. The results of this evaluation are expressed in different energy units, e.g., joules, watts, etc.

3. Index methods. These methods are based on a combination of heterogeneous indicators, which allows their use in the system of multi-criteria evaluations, covering both economic and technical aspects of the project [6]. The feasibility of using multi-criteria evaluations is determined by their comprehensive approach to the consideration of the system [7], which is undoubtedly a strength, but, at the same time, creates the problem of completeness of factors [8].

To determine the individual indicators that characterize the integral efficiency of an energy project, it seems appropriate to rely on the principles proposed in the study of Wang et al. [9]:

- the principle of consistency (comprehensive consideration of the object of research)

- the principle of succession (indicators must correspond to the purpose of assessment)

- the principle of independence (no duplication of indicators)

- the principle of measurability (indicators are measurable quantitatively, or expressed qualitatively)

- the principle of comparability (due to the homogeneity of criteria, or due to their normalization).

Also, when selecting indicators, it is necessary to consider their relevance [10] for achieving the evaluation goals, as well as to consider the theoretical possibility of their calculation, as indicators are valuable only when the data required to determine them can be obtained [11] or modeled. The indicators themselves, depending on the list of stakeholders, their interests, as well as the specifics of the project itself, can vary.

\section{Framework for economic assessment of SLNG projects}

\subsection{The meaning of flexibility}

The main advantage of SLNG as compared to pipeline gas supply is the flexibility of supply chains. The term "flexibility" has a rather broad interpretation, which largely depends on the specifics of the object of study. The flexibility of SLNG projects is determined mainly by the transport link, but the flexibility also includes a relatively low capital intensity of production facilities due to their small volume [12]. Table 1 shows a list of characteristics, which, taken together, determine the flexibility of SLNG supply chains compared to pipeline gas.

The capacity characterizes not only the capacity of the plant but also the carrying capacity of the transport link. With regard to SLNG, it can be significantly expanded, unlike pipelines, which are limited by the design capacity. However, there is a negative 
effect of scale, in one-off production, i.e., the specific capital cost per unit production is higher than that of larger plants.

Table 1 . Specifics determined by the flexibility of low-tonnage LNG.

\begin{tabular}{|c|c|c|}
\hline Flexible (SLNG) & Criteria & Nonflexible (pipeline) \\
\hline Expandable & Capacity & Fixed \\
\hline Decentralized & Consumption & Centralized \\
\hline Unlimited & Integration & Limited by pipeline capacity \\
\hline Replaceable & Market & Single \\
\hline Multiple & Investment decision & Single \\
\hline
\end{tabular}

Consumption determines the endpoints of gas delivery. If SLNG aims at distribution of products to geographically distributed facilities, the pipeline, even if there are branches, usually has one final point of delivery. However, it should be taken into account that the competitiveness of SLNG, in comparison with the pipeline, is achieved only at significant distances and in the presence of many delivery points. Thus, it is fundamentally important to place production facilities in close proximity to the source of raw materials, but at a significant distance from the points of consumption.

Integration characterizes the possibility of interconnecting two supply chains of the same technology. If, for example, two pipelines are connected to a third pipeline, their combined production capacity will be limited either by the capacity of the third pipeline or by the combined capacity of the first two pipelines. The SLNG networks can be safely integrated and supplemented, covering and, if necessary, overlapping markets. As far as the free market is concerned, this allows the development of competition, which is a positive factor that has not been observed in the national market for many years.

The market characterizes the degree of dependence of a project on a specific group of consumers. Pipeline supplies can under no circumstances be reoriented to another region/sales market, whereas in the case of SLNG it will only be necessary to find a satisfactory solution to the logistical issues.

The investment decision determines the investors' flexibility in investing funds. If for the construction of a gas pipeline the decision is made once at the beginning of the project, the scalability of the SLNG allows investment decisions to be broken down into several stages as the capacity of the plant and the logistics network grows. This characteristic makes it possible to move away from a relatively simple single NPV calculation to the use of a decision tree.

\subsection{Direct financial effects}

Direct effects have an immediate impact on the financial flows of the project. The main difficulty of estimation comes down to taking into account all specific factors affecting the project (Table 2). It is necessary to distinguish the direct effects for clients and for the project owners because the direct effects for clients are indirect effects of the project as a whole. 


\subsection{Indirect effects}

The indirect effects created by each project are quite different. In the case of SLNG, much depends on the planned markets for the products. In this case, all the created effects can be conventionally correlated with the stakeholders who are interested in them (Table 3), and with the individual stages of the technological chain (Figure 1).

Table 2. Direct effects of SLNG projects

\begin{tabular}{|c|c|c|}
\hline Project & For project owners & For clients \\
\hline $\begin{array}{l}\text { Replacement of } \\
\text { energy resource } \\
\text { for the purpose of } \\
\text { electric/heat } \\
\text { generation }\end{array}$ & $\begin{array}{l}\text { - Elasticity of energy demand with respect to } \\
\text { price } \\
\text { - Availability of reserve markets } \\
\text { - Cost of land lease } \\
\text { - Cost of natural gas and its reserves } \\
\text { - Cost of equipment } \\
\text { - Range of delivery } \\
\text { - Quality of transportation infrastructure in } \\
\text { the region } \\
\text {-Tax deductions } \\
\text { - Availability of necessary power generating } \\
\text { equipment }\end{array}$ & $\begin{array}{l}\text { - Cost of electric and thermal } \\
\text { energy } \\
\text { - Stability of LNG supply } \\
\text { - Cost of energy storage and } \\
\text { production equipment (in case } \\
\text { of point delivery of LNG). }\end{array}$ \\
\hline Bunkering of ships & $\begin{array}{l}\text { - Intensity of navigation in the target region } \\
\text { - Cost of land lease } \\
\text { - Cost of natural gas and its reserves } \\
\text { - Cost of equipment } \\
\text { - Tax deductions } \\
\text { - Range of delivery } \\
\text { - Quality of transportation infrastructure in } \\
\text { the region. }\end{array}$ & $\begin{array}{l}\text { - Reduction of pollutant } \\
\text { emissions } \\
\text { - Cost of installing additional } \\
\text { equipment } \\
\text { - Change in the range of the } \\
\text { route without refueling } \\
\text { - Change in usable } \\
\text { volume/capacity } \\
\text { - Availability of refueling } \\
\text { infrastructure. }\end{array}$ \\
\hline $\begin{array}{l}\text { Use as a motor } \\
\text { fuel }\end{array}$ & $\begin{array}{l}\text { - Price elasticity of demand for fuel } \\
\text { - Number of large vehicles in the target } \\
\text { region } \\
\text { - Number of gas filling stations in the region } \\
\text { - Navigation intensity in the target region } \\
\text { - Tax deductions } \\
\text { - Cost of land leases } \\
\text { - Cost of natural gas and its reserves } \\
\text { - Cost of equipment } \\
\text { - Range of delivery } \\
\text { - Quality of transportation infrastructure in } \\
\text { the region. }\end{array}$ & $\begin{array}{l}\text { - Cost of installing additional } \\
\text { equipment } \\
\text { - Change in the range of the } \\
\text { vehicle } \\
\text { - Change in useful } \\
\text { volume/capacity } \\
\text { - Cost of gas fuel } \\
\text { - Availability of refueling } \\
\text { stations } \\
\text { - Level of government support. }\end{array}$ \\
\hline
\end{tabular}

We should also emphasize the effect of developing the region's transport infrastructure needed to deliver LNG. This applies both to roads and shipping routes. If we draw an analogy with pipeline delivery, the construction of a pipeline (as an infrastructure object) has only one goal, while the creation of transport corridors supplied with LNG fuel/energy is a positive effect for the region as a whole.

Regarding the directions of SLNG use, it is clear that the priority is energy generation. Its use for bunkering is dictated by MARPOL requirements, but a large-scale transition to this type of fuel has not yet happened [13]. The same is true for motor fuels. The use of SLNG for passenger cars is not feasible due to the high cost of additional equipment and the need to ensure safety requirements. In this regard, co-priced gas has a much more 
favorable position. At the same time, large vehicles with long logistics routes can gain certain advantages by reducing the frequency of refueling, although their load-carrying capacity and capacity may deteriorate.

Table 3. Indirect effects of SLNG projects by stakeholder groups

\begin{tabular}{|c|c|c|}
\hline \multirow{2}{*}{ Stakeholder } & \multicolumn{2}{|c|}{ Indirect effects created by SLNG project } \\
\hline & Positive & Negative \\
\hline Public authorities & $\begin{array}{l}\text { - Attracting investment to the region } \\
\text { - Development of the region's transport } \\
\text { infrastructure } \\
\text { - Ensuring energy security of the region } \\
\text { - Reducing greenhouse gas emissions } \\
\text { (when replacing coal and oil products) }\end{array}$ & $\begin{array}{l}\text { - The need for state co-financing of } \\
\text { projects; } \\
\text { - The need to control and balance } \\
\text { the price level of energy/fuel } \\
\text { produced from various natural gas } \\
\text { derivatives. }\end{array}$ \\
\hline $\begin{array}{c}\text { Investors and project } \\
\text { owners }\end{array}$ & $\begin{array}{l}\text { - Reducing risks of changes in market } \\
\text { conditions. }\end{array}$ & $\begin{array}{l}\text { - Increased competition due to } \\
\text { relatively low investment costs; } \\
\text { - Possible strengthening of the role } \\
\text { of monopolists in terms of resource } \\
\text { supply }\end{array}$ \\
\hline $\begin{array}{l}\text { Suppliers and co- } \\
\text { suppliers }\end{array}$ & $\begin{array}{l}\text { - Increasing the level of localization of } \\
\text { production } \\
\text { - Developing the national market for } \\
\text { materials and technologies. }\end{array}$ & \\
\hline Consumers & $\begin{array}{l}\text { Power supply: } \\
\text { - Gas supply of regions remote from the } \\
\text { main gas pipeline } \\
\text { - Reduction of pollutant emissions } \\
\text { - Development of a network of refueling } \\
\text { stations } \\
\text { Bunkering of ships, or fuelling of large- } \\
\text { size vehicles: } \\
\text { - Increasing the range of the voyage } \\
\text { without refueling } \\
\text { - Reduction of pollutant emissions } \\
\text { - Development of the network of } \\
\text { refueling stations } \\
\text { - State support. }\end{array}$ & $\begin{array}{l}\text { Bunkering of ships, or refueling of } \\
\text { large transport vehicles: } \\
\text { - Reduction of useful volume/cargo } \\
\text { capacity of vehicles; } \\
\text { - Need to buy additional equipment. } \\
\text { Energy supply: } \\
\text { - Rising cost of energy and fuel in } \\
\text { the absence of government support. }\end{array}$ \\
\hline $\begin{array}{l}\text { Environmental } \\
\text { organizations }\end{array}$ & - Reduction of pollutant emissions. & $\begin{array}{l}\text { - Availability of emissions } \\
\text { compared to renewable energy }\end{array}$ \\
\hline Employees & $\begin{array}{l}\text { - Workplaces } \\
\text { - Social guarantees } \\
\text { - Wages. }\end{array}$ & $\begin{array}{l}\text { - High probability of hiring workers } \\
\text { from other regions }\end{array}$ \\
\hline
\end{tabular}

\subsection{System of indicators}

The indirect effects of SLNG cannot be detected in the implementation of a single line of supply. The flexibility of low-tonnage production, which is its strength, imposes a limitation, i.e., the need to plan the network infrastructure, which has significance at the scale of the region of implementation.

With this in mind, Table 4 proposes a list of indicators that allow us to assess the individual indirect effects created by SLNG projects. To avoid the need to normalize the indicators, each of them is presented in index form. 


\section{Positive Effects}

- Attracting investment to the region

i - Reduction of pollutant emissions

- Reducing the risks of changes in market conditions

- Development of a network of gas filling stations

- Increasing the level of localization of production

- Development of the national market of technologies

- Development of transport infrastructure in the region

- Working places

- Social guarantees

- Wages

- Ensuring energy security of the region.
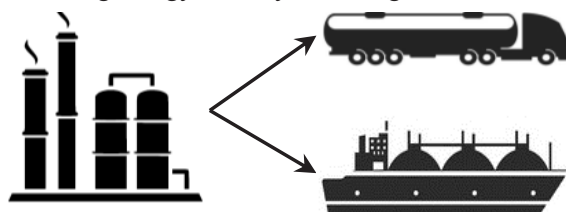

- Gas supply to regions remote from the main gas pipeline.

\section{Negative Effects}

- Need for state co-financing of projects;

- Possible strengthening of the role of monopolists in terms

- Increase in the cost of tariffs and fuel prices in the of resource supply.

absence of state suppor;

- Reduction in the useful volume/carrying capacity of LNG-powered vehicles

- Need to purchase additional equipment.

Fig. 1. Indirect effects of SLNG projects along the process chain

Table 4. Indicators for assessing indirect effects of an SLNG project

\begin{tabular}{|c|c|}
\hline Indicator & Details \\
\hline $\begin{array}{l}\text { Share of private } \\
\text { investment in the project } \\
\left(\mathrm{InE}_{1}\right)\end{array}$ & $\begin{array}{l}\frac{I_{p}}{I_{A}} \text {, where } I_{A} \text { is the total investment in the project, } I_{p} \text { is the private } \\
\text { investment in the implementation of the project. }\end{array}$ \\
\hline $\begin{array}{l}\text { Share of local workers } \\
\left(\mathrm{InE}_{2}\right)\end{array}$ & $\begin{array}{l}\frac{E_{R}}{E} \text {, where } E_{R} \text { is the number of local workers (excluding management and } \\
\text { support staff), } E \text { is the total number of workers of the project. }\end{array}$ \\
\hline $\begin{array}{l}\text { The level of wo } \\
\text { wages (InE }\end{array}$ & $\begin{array}{l}\frac{\mathrm{S}_{\mathrm{P}}}{\mathrm{S}_{\mathrm{R}}} \text {, where } \mathrm{SP} \text { is the average wage level of project workers, } \mathrm{SR} \text { is the } \\
\text { average wage level in the region. }\end{array}$ \\
\hline Mitigation of market risk & when calculating \\
\hline $\begin{array}{r}\text { Level } \\
\text { localiz }\end{array}$ & $\begin{array}{l}\text { is the cost of equipment produced in Russia, } \mathrm{E}_{\mathrm{T}} \text { is the total } \\
\text { oment. }\end{array}$ \\
\hline $\begin{array}{r}\text { Investme } \\
\text { constructic } \\
\text { with improv } \\
\text { (In }\end{array}$ & $\begin{array}{l}\text { of units; IR is the private investment of the project } \\
\text { struction of roads with improved pavement, IA is the } \\
\text { in the project. }\end{array}$ \\
\hline $\begin{array}{l}\text { Growth in the number of } \\
\text { filling stations in the } \\
\text { region }\left(\mathrm{InE}_{6}\right)\end{array}$ & $\begin{array}{l}1+\frac{F_{p}}{F_{A}} \text {, shares of units. } F_{A} \text { is the number of filling stations in the region, } \\
F_{P} \text { is the number of gas filling stations created as part of the project. }\end{array}$ \\
\hline $\begin{array}{l}\text { Increasing the level o } \\
\text { gasification in the regic } \\
\qquad\left(\mathrm{InE}_{7}\right)\end{array}$ & $\begin{array}{l}\frac{G_{P}}{G_{R}} \text {, shares of units. GP is the planned level of gasification of the region } \\
\text { after the project implementation, GR is the level of gasification of the } \\
\text { region before the project implementation. }\end{array}$ \\
\hline $\begin{array}{l}\text { Reduction of pollutant } \\
\text { emissions from } \\
\left.\text { stationary sources ( } \mathrm{InE}_{8}\right)\end{array}$ & $\begin{array}{l}1+\sum \frac{\Delta \mathrm{E}_{\mathrm{SP}}^{\mathrm{i}}}{\mathrm{E}_{R}^{\mathrm{i}}} / \mathrm{i} \text {, fractions of units. " } \Delta \text { " ESP is the reduction in pollutant } \\
\text { emissions at a stationary facility after project implementation }(\geq 0) \text {, ER is } \\
\text { the total pollutant emissions from power generation facilities in the region } \\
\text { before project implementation, } i \text { is the pollutant }\left(\mathrm{CO} 2, \mathrm{CO}, \mathrm{NO}_{\mathrm{x}}, \mathrm{SO}_{2}\right) \text {. }\end{array}$ \\
\hline
\end{tabular}


With regard to InE8, two significant limitations should be noted. Firstly, the hazards of all substances considered are assumed to be equivalent. Secondly, only stationary sources are taken into account, since it is practically impossible to establish a monitoring system for non-stationary objects.

\subsection{Principle of SLNG evaluation}

The calculation of the aggregate index, which characterizes the importance of indirect effects for the economy, is proposed to carry out by formula 1.

$$
\operatorname{InE}_{\mathrm{A}}=\frac{\sum_{\mathrm{k}=1}^{\mathrm{n}} \mathrm{InE}_{\mathrm{k}}}{\mathrm{n}}
$$

where $\mathrm{InE}_{\mathrm{A}}$ - агрегированный индекс, $\mathrm{InE}_{\mathrm{k}}$ is the private indirect effect $\mathrm{k}, \mathrm{n}$ is the number of indirect ones considered (8), according to Table 4.

The integral assessment of SLNG projects depends on the specific conditions of their implementation. In general, it is proposed to conduct the assessment based on the matrix (Figure 2), formed on the basis of the planned values of direct and indirect effects. It is advisable to reflect direct effects in index form, for which the Index of profitability is suitable, the value of which above 1 indicates the investment attractiveness of the project.

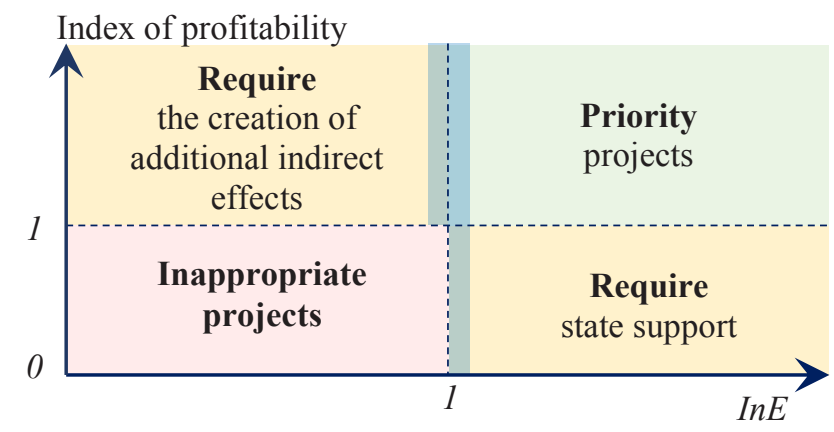

Fig. 2. SLNG project evaluation matrix

When evaluating projects with indirect effects, one of the most frequent problems is the inconsistency of financial and economic evaluation of project implementation. In the free market, the priority is always given to financial efficiency, but, with government participation, projects can receive support to improve their performance. The criterion for providing state support is proposed to consider the importance of indirect effects from the implementation of projects, in order to transfer them from the category "Require state support" to the category "Priority projects."

\section{Conclusion}

This paper presents a theoretical approach to the evaluation of SLNG projects, taking into account their indirect effects. Essence of such effects lies in the possibility of creating positive conditions for various groups of stakeholders, from the point of view of society and the economy, in addition to direct financial flows.

The proposed approach to the assessment of indirect effects includes 8 indices combined into an indicator, which shows the significance of the created indirect effects for the region of project implementation. The integrated assessment of projects is proposed to be based on a matrix, which match indirect and direct effects (profitability index).

The creation of socially significant effects, which are visible from meso-economic point of view is the main criterion for the necessity of state support. It is noteworthy that 
individual micro-projects can not show visible indirect effects, because they are aimed at point-to-point satisfaction of needs. In this regard, SLNG networks development should be based on a clear strategy of production capacity geographical distribution, taking into account the current and projected trends of natural gas consumption in transport sector and heat and power generation.

Acknowledgements. The research was funded by the grant of Russian Scientific Foundation, project 19-78-00036 «Modeling of economic effects from the development of small-scale production of liquefied natural gas».

\section{References}

1. V. Litvinenko The Role of Hydrocarbons in the Global Energy Agenda: The Focus on Liquefied Natural Gas, Resources, 9, 59 (2020)

https://doi.org/10.3390/resources 9050059

2. P.S. Tsvetkov, S.V. Fedoseev Analysis of project organization specifics in small-scale LNG production, Journal of Mining Institute, 246, 678-686 (2021) https://doi.org/10.31897/PMI.2020.6.10

3. P. Tcvetkov, A. Cherepovitsyn, A. Makhovikov Economic assessment of heat and power generation from small-scale liquefied natural gas in Russia, Energy Reports, 6, 391-402 (2020) https://doi.org/10.1016/j.egyr.2019.11.093

4. V.S. Litvinenko Digital Economy as a Factor in the Technological Development of the Mineral Sector, Natural Resources Research, 3(29), 1521-1541 (2020) DOI: 10.1007/s11053-019-09568-4

5. C.J. Cleveland, R.K. Kaufmann, D.I. Stern Aggregation and the role of energy in the economy, Ecological Economics, 32(2), 301-317 (2000)

6. B.W. Ang, W.L. Choong, T.S. Ng Energy security: Definitions, dimensions and indexes, Renewable and sustainable energy reviews, 42, 1077-1093 (2015)

7. A. Gasparatos, A. Scolobig Choosing the most appropriate sustainability assessment tool, Ecological Economics, 80, 1-7 (2012) DOI: 10.1016/j.ecolecon.2012.05.005

8. A. Kumar, B. Sah, A.R. Singh, Y. Deng, X. He, P. Kumar, R.C. Bansal A review of multi criteria decision making (MCDM) towards sustainable renewable energy development, Renewable and Sustainable Energy Reviews, 69, 596-609 (2017)

9. J.J. Wang, Y.Y. Jing, C.F. Zhang, J.H. Zhao Review on multi-criteria decision analysis aid in sustainable energy decision-making, Renewable and sustainable energy reviews, 13(9), 2263-2278 (2009) DOI: 10.1016/j.rser.2009.06.021

10. J. Ren, M. Lützen Selection of sustainable alternative energy source for shipping: Multi-criteria decision making under incomplete information, Renewable and Sustainable Energy Reviews, 74, 1003-1019 (2017) DOI: http://dx.doi.org/10.1016/j.rser.2017.03.057

11. A.L. Dahl Achievements and gaps in indicators for sustainability, Ecological indicators, 17, 14-19 (2012) DOI: 10.1016/j.ecolind.2011.04.032

12. A.E. Cherepovitsyn, F.D. Larichkin, A.G., Vorobiev et al. Economical prospects of advancement in liquefied natural gas production, Gornyi Zhurnal, 2, 59-64 (2018) DOI: $10.17580 /$ gzh.2018.02.09

13. E.G. Katysheva Developing Gas Fields in the Yamal Peninsula as a Factor of Economic Development of the Arctic Zone of Russia, IOP Conference Series: Earth and Environmental Science, 1(302) (2019) DOI: 10.1088/1755-1315/302/1/012127 